Józef MAREcki OFM Cap.

\title{
KULT MATKI BOŻEJ LORETAŃSKIEJ W POLSCE
}

Kult Matki Bożej Loretańskiej zacząl rozwijać się w Italii wraz z pojawieniem się w okolicy miasta Recanati świętego Domku. Na teren Rzeczpospolitej dotarl w początkach XV wieku. Jego znajomość zawdzięczamy polskim patnikom pielgrzymującym do Loreto. Dzięki jezuitom, franciszkanom i bernardynom, kult ten przyjal się na dobre. $Z$ czasem niektóre $z$ krajowych kościołón: i kaplic posiadajacych wizerunki loretaniskie staly się także ośrodkami patniczymi. Kult, którym otaczano figury i obrazy Matki Bożej Loretańskiej promieniowal na caly kraj ${ }^{1}$.

\section{1. ŚWIETY DOMEK W LORETO}

Domek świętej Rodziny z Nazaretu byl uważany za miejsce święte od czasów Wniebowzięcia Najświętszej Maryi Panny. Wedlug palestyńskiej tradycji został zbudowany przez rodziców Matki Bożej - św. Joachima i św. Annę. W jego murach gromadzili się po Wniebowstąpieniu Jezusa Chrystusa na modlitwę i czuwanie apostołowie z Maryja i pierwszymi chrześcijanami.

W 327 r. św. Helena, podczas swej pielgrzymki do Ziemi świętej, odnalazła dom Jezusa w Nazarecie i polecila zbudować nad nim dużą i piękną świątynię. Kościól ten, dwukrotnie burzony i odbudowywany, mieścil w swym wnętrzu

1 N. Wybranowski, Divinae Sapientine Matri in Lauretnun Iconta gratiis clatissinn propositne Reginne Połoniae. Lublin 1746, s. 1 mn; P.H. Pruszcz, Stołecznego miasta Krakoata kościoły $i$ klejnoty. Kraków. 1645 , s. 58-59; K. Kantak, Bernardyni polscy. T. 2. Lwów 1933, s. 178, 260-285; tenże, Franciszkanie polscy. T. 2. Kraków 1938, s. 295; F. Kurowski, Pamiqtki miastn Warsznuy. T. 2. Warszawa 1949, s. 85; K. Kuźmak, Bractzia Mntki Boskiej Wsponożycielki Chrześcijan na ziemiach polskich io XVIII stuleciu. Rzym 1973, s. 23; J. Marecki, Domek Loretníski przy klusztorze kapucynów w Krakowie. „Studia Franciszkańskie". 5:1992, s. 253. 
małe pomieszczenie, $w$ którym według starożytnych relacji zamieszkiwala święta Rodzina podczas swego pobytu w Nazarecie ${ }^{2}$. O. Prosper Viaud z Franciszkańskiej Kustodii Ziemi świętej, badający na początku $X X$ w. teren Nazaretu z czasów Jezusa, stwierdzil, że bazylika wybudowana w czasach Konstantyna miala za zadanie ochronę świętego Domku. Pielgrzymi przybywajacy do Nazaretu przed końcem XIII w. wspominają o murowanym domku, uznawanym powszechnie za mieszkanie Maryi Panny ${ }^{3}$. Mieszkanie świętej Rodziny składało się $z$ dwóch pomieszczen, z których jedno stanowila zbudowana $z$ kamienia izba dlugości $9.65 \mathrm{~m}$ i szerokości $4.09 \mathrm{~m}$, a drugie grota wykuta w zboczu góry. Po opuszczeniu Ziemi świętej przez ostatnich krzyżowców i zajęciu Jej przez mahometan, pielgrzymi nawiedzajacy święte miejsca wspominaja tylko o zburzonej bazylice, pod gruzami której zostały fundamenty Domku*

W l. 1291-1294 Domek nazaretański zostal w częściach przetransportowany droga morską przez krzyżowców na pólwysep Apeniński, do miejscowości nazwanej później Loreto. Warto wspomnieć, że nazwa powstała od wawrzynowego lasu otaczajacego kiedyś Domek. Zapewne obawiano się profanacji czy nawet zburzenia go przez muzułmanów. Abp Loris Capovilla na podstawie dokumentów Biblioteki Watykańskiej udowodnil, że transportem Domku zajmowała się bizantyjska rodzina o nazwisku Angeli. Nazwa tego rodu po latach zrodziła podanie o przeniesieniu świętego Domku przez aniołów. Tezę abp. Capovilli potwierdzaja liczne badania archeologiczne Domku Nazaretańskiego, podczas których $w$ dolnej warstwie zaprawy murarskiej znaleziono monety bite przez księcia Guy de Roche Angeli z końca XIII w. Ks. Jan Loffred $z$ Franciszkańskiego Instytutu Biblijnego w Jerozolimie odkryl $w$ zaprawie murarskiej resztki skorup strusich jaj oraz sukna, pochodzaccego prawdopodobnie $z$ ubrań krzyżowców. W średniowieczu strusimi jajami wzmacniano na Wschodzie zaprawę murarska, a resztki strojów krzyżowców musiały się dostać pomiędzy kamienie podczas składania ścian Domku po przewiezieniu Go na okrętach w okolice Ankony ${ }^{5}$.

Badania przeprowadzone na zlecenie Stolicy Apostolskiej w latach 1531, 1672, 1751 dowiodły, że Domek Nazaretański w Loreto zostal usytuowany na wiejskiej drodze. Nie posiada fundamentów, a pod dolną warstwá ścian

2 J. Marecki, Domek Matki Boミ̇ej Loretańskiej przy kościele OO. Knpucynów iv Krnkowie. Kraków 1986, s. 37. (Mps w posiadaniu autora).

3 W. Garratt, Loreto. Recanati 1897, s. 46-47; G.A. Cenni storici sulle predigiose translazioni della Santa Casa Nazaretana ora venerata in Loreto. Ripatransone 1862, s. 9-13; G. Marella, A Loreto memorie impresioni e ricordi. San Vito 1885, s. 10-11; H. Warachim, Modlitetwik loretaíski. Ancona 1981, s. 23-24.

$\$$ Vuillaume, Historya przeniesienin Domku Loretnúskiego. Kraków 1885, s. 7-8; K. Posadny, Nazaret miasto Najświętszej Rodziny, „Przewodnik Katolicki”. 6:1928, s. 3-5; H. Warachim, Loreto. Sanktuarium świętego Domku. Ancona 1981, s. 20.

5 G. Santarelli, Loreto. Bologna 1983, s. 3-13. 
zachowaly się kamienie, piasck, muszelki i śmieci oraz zgnieciony przydrożny krzak glogu. W 1875 r. prof. Franciszek Ratti z Rzymu przeprowadzil analizę próbek kamieni ze ścian świętego Domku i kamieni z okolic Nazaretu. Po zbadaniu ich wlaściwości fizycznych i chemicznych prof. Ratti stwierdził, że ściany Domku zostaly zbudowane z kamienia występujacego w Palestynie, w okolicy Nazaretu ${ }^{6}$. Autentyczność Domku przeniesionego do Loreto potwierdzaja liczne objawienia i cuda, które miały miejsce w XIX w. Potwierdzali ja także swym autorytetem kolejni papieże od XV w. Jako pierwszy do Loreto pielgrzymowal papież Mikolaj V w 1449 r. On też wydał bullę stwierdzająca, że Domek Loretański jest prawdzirvym mieszkaniem świętej Rodziny. Syktus IV w 1471 r. nadal świętemu Domkowi miano „Alma Domus”. W późniejszym czasie w oltarzu umieszczono napis: "Deiparae Domns in qua caro factum est". Prawie wszyscy papieże od Mikolaja V do Jana Pawła II pielgrzymowali do Loreto i specjalnymi dokumentami potwierdzali autentyczność świętego Dom$\mathrm{ku}^{7}$. Bardzo szybko rozwinał się kult loretańskiego sanktuarium. Już w pierwszych latach $\mathrm{XV} w$. do Loreto przybywały pielgrzymki z terenu dzisiejszych Niemiec, Hiszpanii, Francji, a także pojedynczy Polacy ${ }^{\delta}$. Początkowo przedmiotem kultu byly ściany świçtego Domku, a z biegiem czasu kult loretański został przeniesiony na cudowna, laskami slynącą statuę ${ }^{9}$.

Od pol. XV w. wzrosła liczba pielgrzymów przybywających do Loreto. Popularność swa zawdzięczal Domek przede wszystkim broszurkom autorstwa bł. Jana Spagnoli i Teramena. W ciagu wieków Domek nawiedzaly rzesze pielgrzymów. Reprezentowali oni wszystkie narodowości, grupy społeczne, zawody i stanowiska. Niewiele z wotów i ofiar przez nich skladanych zachowało się do naszych czasów. Część przerobiono na inne ozdoby, część zaginęla i zostala zrabowana w 1797 r. przez wojska Napoleona ${ }^{10}$.

Tytuły, którymi obdarzano Matkę Bożą czczoną w loretańskim wizerunku, układano w grupy. Z takich poszczególnych grup powstała później litania, zwana popularnie Litanią Loretańską ${ }^{11}$. Na wzór świętego Domku budowano kaplice i kościoly, ulice przylegajace do tych budowli nazwano loretańskimi. Bywalo, że place przed sanktuariami loretańskimi zamieniały się $w$ targo-

6 G.A., dz. cyt., s. 24; J. [Vives y Tuto], Veritns Trnnslationum Almae Domus Lautatmae. Roma 1889 , s. $5-7,26-41$.

7 Oryginal bulli, podobnie jak i inne dokumenty dotyczące Santa Casa znajduje się w archiwum miasta Recanati.

8 Vuillaume, dz. cyt., s. 53; G. Dubiecki, Nazareth i Loret. Kraków 1892, s. 30.

9 Obecnie wewnątrz Domku znajduje się kopia cudownej figury gdyż pierwotna spaliła się w lutym $1921 \mathrm{r}$.

10 Misson, Podróa do Włoch. Haga 1694, s. 19; Arsenio d'Ascoli, La Snnta Casa. Loreto 1971, s. 65-72; J. Marecki, Domek Matki Bołej..., s. 41.

11 X.S.J., Litanja. W: Encyklopedja Kościelna. T. 12. Warszawa 1879, s. 252; P. Leszczyński, Maryjn w litmininch loretańskich wielbiona. Kraków 1875, s. 17-19; J. Kutnik, Litanin loretaískn. Kraków 1983, s. 24 . 
wiska i place handlowe. Święty Domek w Loreto, stojący niegdyś pośród wawrzynowego lasu, a dziś pod kopula wspanialej bazyliki, byl i jest uważany za jedno $z$ centralnych ośrodków maryjnego kultu na świecie. Wśród pielgrzymów nie zabrakło również mieszkańców z nad Wisły, Dniepru i Niemna.

\section{POLACY W LORETO}

W Loreto, w Domku świętej Rodziny, zachowaly się liczne ślady pobytu polskich pielgrzymów. Kronikarze loretańscy nie byli $w$ stanie odnotować wszystkich przybywających do sanktuarium. Zapisywano tylko nazwiska ważnych osobistości: królów, członków ich rodzin i delegatów, książąt i biskupów. Odnotowano także $w$ księgach darowizn tych, którzy w skarbcu skladali cenniejsze wota i ofiary.

Pierwszym znanym pielgrzymem z Polski nawiedzającym święty Domek byla żona Zygmunta II Augusta. Prawdopodobnie byla to trzecia żona króla - Katarzyna. Oczywiście, przed królowa przybywali do Loreto inni Polacy, jednak nie znamy ich nazwisk i czasu pobytu. Prawie każdy $z$ polskich pątników niósl do Loreto rodzinne pamiątki i pieniężne ofiary. W okresie późniejszym sanktuarium loretańskie nawiedzil Stefan Batory (zanim zostal królem polskim) i Bona Sforza ${ }^{12}$.

Najwięcej Polaków przybywalo do Loreto od XVI do XVII w. Z tego okresu pochodza ofiary zlożone przez Polaków w świętym Domku: złotem haftowane i perlami wyszywane szaty liturgiczne, kielichy, monstrancje wykladane rubinami, zlote i srebrne lampy oliwne do oświetlania wnętrza sanktuarium, wiele złotych krzyży, pierścieni, serc i łańcuchów. Do czasów obecnych wewnątrz Santa Casa znajduje się złota lampa oliwna oświetlająca cudowną figurę, wagi około $10 \mathrm{~kg}$. Jest to dar króla Zygmunta Il Wazy, wielkiego czciciela Matki Bożej Loretańskiej. Od tego samego króla pochodzi wotum wykonane ze zlota, majace ksztalt dziecka. Lampę oliwną ze srebra ufundowal $z$ okazji pobytu $w$ Loreto kanclerz koronny Wojciech Radziwiłk. $\mathrm{Z}$ początku XVII $\mathrm{w}$. pochodzi zlote serce wysadzane 149 diamentami, które jest darem polskiego biskupa Augusta o nieznanym nazwisku. W niszy oltarzowej w pol. XVIII w. ustawiono zloty relikwiarz ofiarowany przez króla Władyslawa III oraz krysztalową filiżankę oprawioną w złoto i perły, która przysłała do Loreto nieznana z nazwiska polska księżniczka. Wśród wielu składanych darów na uwagę zasługuja dwie lampy srebrne, ofiarowane przez jednego $z$ polskich pielgrzymów. Ze względu na piękno i artystyczne wykonanie przez długi czas zdobily wnętrze sanktu-

12 G.A., dz. cyt., s. 30; H. Warachim, Loreto..., s. 56. 
arium $^{13}$. Do Loreto pielgrzymowal św. Stanisław Kostka podróżując z Wiednia do Rzymu ${ }^{14}$.

Najwspanialsze polskie dary $w$ Loreto pochodza od rodziny Sobieskich. Na ręce papieża Innocentego XI poslal król Jan III do Loreto sztandary, srebra, plótna i namioty zdobyte pod Wiedniem i Parkanami. Wcześniej, bo po walkach pod Chocimiem, posłal Sobieski do loretańskiego sanktuarium swa szable z napisem: "Victoria Chocim. Maria Loretana - ora pro nobis". O szczególnym kulcie króla Jana Sobieskiego do Matki Bożej Loretańskiej świadczy oddanie pod Jej opiekę calego wojska w dniu 15 sierpnia 1683 r., tj. przed wyprawa wiedeńska, w kaplicy loretańskiej kościola Mariackiego w Krakowie a także przed bitwa pod Parkanami w dniu 9 października 1683 r. Loretańskie pamiątki po Sobieskich pozostały także $w$ kraju: różaniec z loretańskim medalionem, obraz przywieziony przez króla Jana III z odsieczy wiedeńskicj $z$ napisem zapewniajacym o zwycięstwie, szable z loretańskimi wizerunkami w rękojeściach.

Kult Maryjny, który zaszczepil Janowi jego ojciec Jakub, podzielala w ówczesnych czasach większość szlachty. Sobieski - jako hetman, a później król pielgrzymowal do sanktuariów maryjnych $w$ całej Rzeczpospolitej. Nic też dziwnego, że gdy wkroczył $w$ mury Wiednia, udal się do kaplicy loretańskiej przy kościele augustianów, odśpiewal „Te Deum laudamus” i przyjąl Komunię św. z rąk papieskiego legata o. Marka z Aviano. Żona króla Jana III, Maria Kazimiera, już jako wdowa, pielgrzymowala do Loreto i złożyla tam $w$ darze od rodziny Sobieskich zlotą monstrancje, ozdobiona drogimi kamieniami ${ }^{15}$.

Znajomość loretańskiego sanktuarium $w$ Polsce $w$ XVI i l pol. XVII $w$. byla mala. Kult loretańskiego sanktuarium rozwinal się $w$ Polsce $w$ późniejszym czasie. Do Loreto udawala się zazwyczaj szlachta, a już bardzo rzadko mieszczanie. Do wyjątków należała pielgrzymka do Italii kogoś z rodziny chłopskiej. Milym akcentem ze strony kustoszów loretańskich bylo oddanie pod opiekę Polaków (w okresie zaborów) jednej z kaplic, którą w późniejszym okresie nazwano kaplica polska. Wcześniej, bo już przed 1772 r., w kaplicy tej gromadzili się polscy patnicy przy tablicy upamiętniajacej zwycięstwo króla Jana III nad Turkami w $1683 \mathrm{r}^{16}$.

13 D. Lasiński, Wiadoność o Domiku N[njświętszzj] Panny Maryi w Lorecie. Rzym 1783, s. 353; Arsenio d'Ascoli, dz. cyt., s. 67, 71; C. Dubiecki, dz. cyt., s. 35.

14. Nazwisko świętego umieszczono na tablicy "Elencha dé Santi e Beati" znajdujacej się wewnatrz bazyliki loretańskiej.

15 Bibliografię dotycząca kultu loretańskiego Sobieskich zestawil: J. Marecki, Domek Mntki Bo:iej..., s. 44-46.

16 W. Smoczyński, Wspomnienin o polskiej pielgrzymce do Rzymu wo roku 1888. Kraków 1889, s. 213; V. Gabrielli, La capella polacca. „Il Messaggio della Santa Casa”. 9:1983, s. 271; H. Warachim, Polskie prinintki w Loteto. Kraków 1983 s. 70. 
Za sprawą patników kult Matki Bożej Loretańskicj i świętego Domku zostal przeniesiony na ziemię polską. Przyczyniły się do tego wielojęzyczne broszury o cudownym przeniesieniu świętego Domku, które można bylo nabyć w Loreto oraz kopie laskami słynacego wizerunku loretańskiego, przywożone przez pielgrzymów do kraju ${ }^{17}$.

\section{LORETY W POLSCE}

Caly okres XVII i XVIII w. to zloty okres kultu loretańskiego na terenie Rzeczpospolitej. Chociaż niewiele osób pielgrzymowalo do Loreto, to jednak kult Matki Bożej Loretańskiej przypisywany miejscowym wizerunkom rozwijał się bardzo szybko. Najszersze kręgi zataczal wśród magnaterii i szlachty. Z inicjatywy pielgrzymów powracajacych $z$ Italii budowano domki i kaplice loretańskie, a najbogatsi pątnicy sprowadzali zagranicznych budowniczych i finansowali budowy (Praga - król Władyslaw IV; Chodel - abp Samuel Maciejowski; Kalisz - Skotniccy; Iwje - Jan Kiszka; Lublin bp J. Swirski; Kraków, kościól Mariacki - Szembekowie, kościól p.w. św. Piotra i Pawła rodzina Czarneckich, kościól p.w. św. Krzyża - Lemieszowie, kościól p.w. św. Andrzeja - B. Myszkowska, domek loretański - Wojciech Dembiński ${ }^{18}$.

Na przestrzeni 300 lat (XVI-XVIII w.) powstały na terenie Polski 33 ośrodki kultu loretańskiego, w tym 6 domków (Goląb, Kraków, Lwów, Piotrkowice, Praga i Stwolowicze), 4 kościoły p.w. Matki Bożej Loretańskiej (Chodel, Lwów, Sierp i Telsze), 10 kaplic loretańskich (Anglona, Godów, Kraków - klaszlor klarysek, Kraków - kościól św. Piotra i Pawła, Kraków - kościól mariacki, Kraków - kościól św. Krzyża, Olkienniki, Poznań, Wilno, Wojnicz) oraz 13 innych miejsc z cudownymi wizerunkami (Borówno, Bystrzyca, Iwje, Kalisz, Kraków - kościół św. Barbary, Lublin, Mińsk, Nieśwież, Olkusz, Posinie, Poszyrwianty, Stary Sącz, Żółkiew) ${ }^{19}$.

Domki loretańskie budowano według wymiarów Santa Casa (w rzucie poziomym) co było warunkiem uzyskania przywilejów i odpustów. Zazwyczaj byly bogato zdobione i oświetlone oliwnymi lampami. Oltarze pokrywano płytami marmurowymi lub stiukami. W ten sposób nawiązywano do wystroju świętego Domku. Na ścianach zewnętrznych umieszczano oltarze z obrazami świetej Rodziny. Matki Bożej. św. Józefa, św. Anny i św. Joachima, rzadziej postacie starotestamentalnych proroków jak to mialo miejsce w Golębiu ${ }^{20}$.

17 K. Puchala, Polski Loret. "Pokój i Dobro". 12:1938, s. 196; H. Warachim, Loreto..., s. 5-6.

18 J. Marecki, Domek Mntki Bożej..., s. 47.

19 J. Marecki, Wykaz wå̇niejszych ośrotkózo kultu loretaniskiego w Polsce w jej granicach historycanych. Kraków 1986, s. 7. (Maszynopis w posiadaniu autora).

20 Ł. Golębiowski, Opis Warsznoy. Warszawa 1827, s. 107; F. IJanochal, Loretto przy kościele OO. Kapucynów w Krakowie. Kraków 1889, s. 20; [E. Nowakowski] Waclaw z Sulgostowa, O cu- 
Każdy domek skladal się z dwóch pomieszczeń: kuchenki i pokoiku, które rozdzielal oltarz. W kuchence byl kominek, szafka na naczynia oraz drzwi prowadzące na zewnątrz domku. Pokoik - miejsce upamiętniajace Zwiastowanie byl większy. Ściany zdobily freski i malowidla przedstawiajace sceny z życia świętej Rodziny. Pokoik mial jedno okno i dwoje drzwi. W kuchence centralne miejsce zajmowal wizerunek loretański. Nad oltarzem umieszczano postacie aniolów, symbolizujace przeniesienie Domku do Loreto. Jedyne okno, które oświetlało wnętrze domku nie przepuszczalo dostatecznej ilości światla, dla tego panował tam pólmrok, rozjaśniany oliwnymi lampkami. Wy wolywało to nastrój tajemniczości i donioslości. Warunki takie sprzyjały skupieniu i modlitwie.

Wota, które przynosili pielgrzymi wieszano badź bezpośrednio obok wizerunku, bądź na ścianach wewnętrznych domku. Domki obudowywano korytarzami lub krużgankami. W ten sposób nawiązywano do Loreto, gdzie święty Domek stoi wewnatrz wspanialej bazyliki. Korytarze i krużganki pelnily przede wszystkim funkcje praktyczne, gdyż procesje wokół domków można było odbywać bez względu na warunki atmosferyczne. Podczas Mszy św. i nabożeństw gromadzili się w krużgankach wierni²! Krużganki i domek budowano pod jednym dachem. "Dwie kondygnacje domów $i$ dachów l... / przedstawiaja jakby ziemię z niebem, przez Matkę Boża połaczone. Parterowe ściany stanoziq otoczenie jakby płaszczem ochraniajace właściwe ściany Domku"22. Na dachach umieszczano postacie aniolów symbolizujących przeniesienie świętego Domku.

Kościoły pod wezwaniem Matki Bożej Loretańskiej budowano najczęściej w XVI i XVII w. Kościól na górze Loret w Sierpcu ukończono w 1513 r., a kościoly w Telszach i Chodlu w drugiej dekadzie XVII w. Kościól w Sierpcu ma w glównym oltarzu cudowną figurę zwana loretańską. Nie przypomina ona jednak swym wyglądem oryginalu $z$ Loreto. Kościół ten wybudowano jako wotum dziękczynne za ustapienie epidemii czarnej ospy na przelomie XV i XVI w. Kościoły w Telszach i Chodlu mają w głównych oltarzach obrazy przedstawiające wizerunki loretańskie ${ }^{23}$. Zazwyczaj Loretem nazywano kościól z najbliższym otoczeniem. Był więc Loret sierpski, czyli wzgórze z zabudowaniami kościelnymi, dawnym domem mansjonarzy i klasztorem benedyktynek - fundowanymi przez Zofię Potulicka w 1624 r. Loret w Chodlu

doinych obrazach io Polsce Praelujsiziętszej Matki Bođej. Kraków 1902, s. 387; W. [Strzemecki], Krakouskie Loreto. "Wzlot Seraficki”. 3:1935, s. 16; Polski Donek Loretaniski. „Pokój i Dobro". 11:1938, s. 155; S. Michalczuk, Domek Loretníski w Gołębiu. W: Treści dzieł iszituki. Warszawa 1969, s. 157, 168.

${ }^{21}$ J. Marecki, Domek Mrtki Bożej..., s. 49 (przypis 34, 35).

22 [Janocha], Loretto..., s. 19.

23 [W. Bystrzanowski], Thaumaturge in sua aede prope oppidum Chadel Virgini Laurentanae in morte et zariis infirmitatibus sospitatrici, in peste, hostilitate et periculis praesidii Collegii Lublinensis Soc. J. domesticae tutelarii et onnium ad se confugientium communi matri, se summue indignum triennalis cursus laborem deticat a. 1735 juratum Mariam honoris mancipium. Lublin 1735, s. 1; S. Baracc., Cudoivue abrazy Matki Najśuiętszej io Polsce. Lwów 1891, s. 245; L. Paprocki, Laski cudorone przy kościele sierpskin Wrieborusięcin Bogarodzicy Panty. Warszawa 1627, s. 15. 
obejmował kościól i wzgórze, a Loret w Telszach cała centralną część miasta z kościolem i pobliskim klasztorem bernardynów fundacji Pawła Sapiehy ${ }^{24}$.

Kaplice loretańskie najczęściej byly dobudowywane do kościołów. Loretem określano także kaplice lub ol tarz, w których obok innych wizerunków umieszczano figurę lub obraz loretański. W Mińsku, w kościele jezuitów, obraz loretański znajdowal się nad glównym oltarzem. Taras z obrazem nazywano górnym ołtarzem lub górna kaplicą loretańską. Jedynie w Godowie i Wojniczu wybudowano oddzielne od kościola kaplice. We wszystkich kaplicach centralne miejsce zajmowal wizerunek loretański, ściany ozdabiano nagrobkami i epitafiami zmarłych fundatorów i dobrodziejów, niekiedy wotami. Nad oltarzami umieszczano postacie lub obrazy aniolów. Wejścia zamykały często kute mosiężne kraty (Kraków - kościól Mariacki, Poznań). Podobnie zabezpieczano okna i luminaria $w$ dachach. Pod kaplicami budowano krypty, w których składano ciała zmarlych fundatorów, dobrodziejów i kapłanów ${ }^{25}$. Niejednokrotnie fundatorowie obok kościołów i kaplic loretańskich budowali klasztory, zakonnikom powierzajac opiekę nad Loretami (Iwje, Kalisz, Piotrkowice, Praga, Telsze - bernardyni, Chodel, Mińsk - jezuici, Kraków - kapucyni, Lublin bonifratrzy, Anglona - dominikanie). $Z$ powodu znacznego naplywu pielgrzymów ordynariusze dla większych Loretów (Sierpc, Chodel, Wilno, Kraków, Goląb) ustanawiali kaznodziejów i spowiedników. Ponadto w kaplicy loretańskiej kościola Mariackiego w Krakowie oraz w domkach praskim i krakowskim gloszono kazania w języku niemieckim dla Niemców ${ }^{26}$.

$W$ przeciwieństwie do sanktuarium $w$ Loreto i do innych krajów, polski kult Matki Bożej Loretańskiej rozwijai się raczej wokół wizerunków, a nie wokól wcześniej omawianych budowli. Wizerunki te w dwojaki sposób trafiały do kościołów i kaplic. Często byly przedmiotem kultu w prywatnych domach lub kaplicach, skąd jako cudowne byly przenoszone do publicznych miejsc kultu. Nie znano ich pochodzenia, dlatego tworzono czesto podania o ich niezwyklych twórcach, np. św. Łukasz, oraz o cudownych zjawiskach i związanymi z tym objawieniami. Inne wizerunki zostały przywiezione do Polski przez pielgrzymów powracajacych z Loreto, gdzie wykonywali je nieznani z nazwiska rzeźbiarze i kopiści. Nie przedstawiają one jednak większej wartości artystycznej.

Wszystkie wizerunki loretańskie w krajowych ośrodkach kultu Matki Bożej Loretańskiej możemy podzielić na cztery zasadnicze grupy.

Pierwsza grupe stanowia figury wykonane na wzór cudownej cedrowej statuy $z$ Loreto. Maja one ozdobna dalmatykę płócienną lub wykonana z drzewa, łạcznie $z$ całą figurą. Przykładem może być najstarsza figura $z$ krako-

\footnotetext{
24 J. Marecki, Domek Mntki Bożej..., s. 51.

25 Tenże, Wyknz waż̀iejszych aśrodkóil..., s. 1-2, 6.

26 [W. Nowakowski], dz. cyt., s. 300, 316.
} 
wskiego domku lub laskami slynąca figura z Stwolowicz. Sa to wienne kopie oryginalu. Figury te - wszystkie drewniane - wykonane sa $w$ ten sposób, że Madonna na swym lewym ręku trzyma Dzieciątko błogosławiące prawa ręka, a w lewej trzymające kulę ziemską z krzyżykiem.

Druga grupe stanowią statuy, które nie są kopiami figury loretańskiej, lecz zostaly zaadoptowane dla potrzeb kultu loretańskiego. Madonna trzyma więc Dzieciątko $w$ dowolnej pozie na prawej ręce. Niekiedy też figura okryta jest ozdobna suknią. Do grupy tej należy zaliczyć statuę sierpską, piotrkowicką, wileńską, olkiennicką i poszyrwiancka. Niekiedy, tak jak figura z Sierpca, byly one wcześniej czczone jako cudowne, lecz nie utożsamiano ich z loretańskimi. Statue poszyrwiancką otrzymala Anna Radziwilłowa (+ 1616) od papieża Klemensa VIII podczas pielgrzymki do Rzymu i Loreto. Zanim trafila w 1621 r. do kościoła, odbierala cześć w prywatnej kaplicy Radziwiłłów.

Trzecią grupe wizerunków stanowią obrazy przedstawiajace Matkę Bożą na wzór statuy loretańskiej. Obrazy te znajdowały się w Nieświeżu, Żółkwi, Chodlu i w Mińsku. Na obrazach tych nad glowami Maryi i Dzieciątka umieszczano zlote korony lub diademy. Byly to jedyne ozdoby na tych wizerunkach. Na niektórych obrazach wizerunck Madonny otaczaja wstegi lub labry $z$ napisami sławiacymi imię Maryi. Te charakterystyczne napisy występuja np. na tzw. obrazie Sobieskiego i wizerunku z podkrakowskiej Woli Justowskiej.

Ostatnią grupe stanowia obrazy, które nie przedstawiaja postaci Madonny z Loreto, lecz sa tylko zwane loretańskimi. Obrazy te często ozdabiano srebrnymi sukienkami, koronami i koralami. Jedynym znakiem, że jest to obraz Matki Bożej Loretańskiej był podpis pod wizerunkiem lub pobożne przekonanie wiernych. Przykładem takiego wizerunku jest obraz z kaplicy loretańskiej kościola Mariackiego w Krakowie ${ }^{27}$.

W trzydziestu trzech sanktuariach i miejscach kultu loretańskiego na terenie przedrozbiorowej Polski znajdowalo się piętnaście figur i osiemnaście obrazów, uznawanych za cudowne, przedstawiających Matkę Bożą Loretańską.

\section{NABOŻEŃSTWO LORETAŃSKIE}

Już w I poł. XVII w. ustaliło się polskie nabożeństwo loretańskie. Charakterystycznym jest, że wszystkie modlitwy, litanie, a później i psalmy odmawiano lub śpiewano $w$ języku polskim. Codziennie rano, zwlaszcza $w$ miastach, śpiewano w Loretach Godzinki o Niepokalanym Poczęciu Najświętszej Maryi Panny, po czym brano udział we Mszy św. odprawianej według formularza o Matce Bożej. Wieczorem pod przewodnictwem kaplana śpiewano

27 J. Marecki, Domık Matki Bożej..., s. 53-55. 
lub odmawiano Litanię Loretańską, a $w$ niedziele nieszpory $k u$ czci Matki Bożej. W soboty gloszono kazania tematycznie związane $z$ wezwaniami litanijnymi ${ }^{28}$.

W domkach loretańskich $w$ każda sobotę odbywały się procesje po krużgankach. Praktykowany byl też obrzẹd oczyszczania wizerunków loretańskich. Czynności te wykonywal kaplan odmawiając przepisane modlitwy. W niektórych domkach, np. w Krakowie, Pradze czy Wilnie odprawiano nabożeństwa loretańskie lub nowenny do Matki Bożej Nieustającej Pomocy, podczas których zanoszono dziękczynienia i prośby składane przez wiernych na karteczkach w zakrystiach tychże świątyñ ${ }^{29}$.

Do praskiego domku urządzano $w$ soboty procesje $z$ kościolów warszawskich. Najpopularniejsze były procesje z kościolów jezuitów i pijarów. Udział w nich $w$ większości brala mlodzież. Z krzyżem, kościelnymi sztandarami, orkiestra i śpiewem udawano się do Loretu, gdzie śpiewano litanię, odmawiano różaniec i odprawiano nowennę do Matki Bożej. Po błogosławieństwie Najświętszym Sakramentem powracano procesyjnic do Warszawy ${ }^{30}$. Znana, prawie zawsze odmawiana przed wizerunkiem Matki Bożej w loretańskich sanktuariach, była $\mathrm{i}$ jest nadal modlitwa zaczynajaca się od slów "O Maryjo, Dziewico Niepokalana"31.

Dla podkreślenia doniosłości nawiedzenia Loretów dokonywano $\mathrm{w}$ nich wystawienia Najśw. Sakramentu i blogoslawiono Nim wiernych po zakończonych modlitwach. Tam, gdzie wizerunki byly za zasłonami, podczas ich odslaniania śpiewano antyfone „Witaj Królowo, Matko Miłosierdzia”, lub "Zdrowaś, zdrowaś". Po nabożeństwie lub po Mszy św. zasłaniano wizerunek $w$ ciszy lub przy śpiewie popularnych pieśni maryjnych ${ }^{32}$.

\section{INNE PRZEJAWY KULTU}

Najbardziej widocznym przejawem kultu Matki Bożej Loretańskiej w Polsce było składanie $w$ Loretach darów. Większość wizerunków miała korony lub diademy ofiarowane przez wiernych. Figury posiadały ozdobne dalmatyki wyszywane perłami i złota nicią w ksztalcie księżyców (Wilno, Sierpc, Ol-

28 [L. Doliński], Noiny Brewiarzyk Tercjarski. Kraków 1928, s. 271-282; P. Leszczyński, Mnj loretniski. Warszawa 1889 , s. 20; Tenże, Majowe uwielbienie Maryi. Warszawa 1894, s. 18; S. Michalczuk, dz. cyt., s. 164.

29 P.H. Pruszcz, Klejnoty..., s. 172; F. [Janochal, Loretto..., s. 55-56.

30 A. Dubowski, Warsziuskie Loreto, "Przewodnik Katolicki”. 21:1968, s. 198; M. Mińkowski, Kościót Matki Bo‡̇ej Loretańskiej - Sanktuırium Pragi. Warszawa 1950, s. $74-75$ (Mps w posiadaniu autora); B. Prendka, Loreto. "Gość Niedzielny”. 23:1960, s. 4.

${ }_{31}$ J. Marecki, Domek Matki Bożej..., s. 164.

32 [A. Wojnar], Polski Loret. Kraków 1939, s. 69-71; J. Marecki, Domek Matki Boł̌cj..., s. 57, 165-167. 
kienniki, Kraków, Praga, Chodel). Tak jak w Loreto, tak i w sanktuariach polskich jedıa szata okrywala obie postacie. Obrazy ozdabiano pozlacanymi i srebrnymi sukienkami, kolpakami, lańcuchami, sznurami perel oraz korali. Oprócz kosztowności ofiarowano kielichy, ornaty, komże, kapy, świeczniki lub lampy. Często pod wizerunkami umieszczano tabliczki z wygrawerowanymi dziękczynieniami i prośbami ${ }^{33}$. Niektóre Lorety, zwłaszcza te najstarsze: Sierpc, Praga i Stwolowicze mialy skarbce, w których przechowywano ofiary pielgrzymów. Szczególną opieka otaczano dary królewskie Zygmunta Starego, Zygmunta III Wazy, Wladyslawa IV i Jana III Sobieskiego. Pozostałe Lorety były raczej lokalnymi, a co najwyżej diecezjalnymi ośrodkami kultu maryjnego. Stąd też wota $\mathrm{i}$ dary $w$ nich skladane były uboższe. Prawie wszystkie sanktuaria podzielily ten sam wspólny los. W XVIII i XIX w. wpadly w ręce zaborców, którzy przeprowadzali likwidacje kościolów i konfiskaty klasztorów. Bardzo niewiele $z$ wyżej wymienionych kosztowności zachowało się do czasów nam obecnych: kilka kielichów i ornatów w Sierpcu, antepedia oraz srebrna sukienka $w$ kościele Mariackim w Krakowie ${ }^{34}$.

Osobliwym wyrazem kultu bylo ustanawianie fundacji dla mansjonarzy, czyli kaplanów, których obowiązkiem bylo śpiewać sobotnie litanie i niedzielne nieszpory przed loretańskimi wizerunkami. Wyróżniali się w tym krakowscy i sierpscy mieszczanie ${ }^{35}$.

Niektórzy pisarze historyczni i kronikarze wspominają o licznych cudach, jakie miały miejsce za wstawiennictwem Matki Bożej Loretańskiej. Niestety, wiele ksiag łask $\mathrm{i}$ cudów oraz kronik $\mathrm{z}$ ośrodków kultu loretańskiego nie dochowalo się do naszych czasów. Posiadamy zaledwie kilka opisów cudów z domku krakowskiego, kaplicy loretańskiej kościoła św. Barbary w Krakowie i Loretu sierpskiego. Wolno przypuszczać, że w większości Loretów dokonywały się cudowne zjawiska i uzdrowienia, gdyż dzięki nim kult loretański rozszerzal się i wzrastal ${ }^{36}$.

Do rozwoju kultu Matki Bożej Loretańskiej przyczynily się w dużej mierze wydawnictwa, a także obrazki i medaliki przedstawiające wizerunki loretańskie. Bardzo szybko, bo już w XVII i XVIII w. zaczęto je rozprowadzać w Sierpcu,

33 P.H. Pruszcz Morie Łaski Boskiey. Kraków 1740, s. 70; S. Ulanecki, Domek Dziewicy wo Nazaret i Loreto, Warszawa 1862, s. 274; D. Chodźko, Anglona - kościót i klasztor OO. Dominiknnów, Warszawa 1856, s. 30-34; [W. Nowakowski], O cudownych obrazach..., s. 300; Tenże, Katalog cudowntych obrazów Matki Bo:̇j w Polsce. (Maszynopis w Ar. Prow. Krak. oo. Kapucynów w Krakowie, nr 156, 379, 404-405, 435, 568, 646-647, 843); A. Dubowski, art. cyt., s. 198.

34 J. Mączyński, Pamiqtka z Krakowa. Kraków [brw], s. 185; ]. Marecki, Domek Matki Bożej..., s. $58-59$.

35 ]. Mączyński, dz. cyt., s. 185; W. [Gazda], Lorety wo Polsce. „Wzlot Seraficki”. 3:1938, s. 14-15; S. Michalczuk, art. cyt., s. 161.

36 S. Ulanecki, dz. cyt., s. 274; A. Wejnert, Staroźymości warszawskie. T. 3. Warszawa 1858, s. 10; [A. Kleczkowski], Śtwięte pamiqutki Krakowa. Kraków 1883, s. 295, 418; F. [Janocha], Loretto..., s. 33 . 
Wilnie, Chodlu, Pradze, Lublinie i w innych miejscowościach. Wydawano także książki o świętym Domku i Jego cudownym przeniesieniu. Ponad to książki zawieraly opisy polskich Loretów i wizerunków, które się w nich znajdowaly. Na końcu książek zamieszczano modlitwy i slowa pieśni śpiewanych iv domkach i kaplicach loretańskich ${ }^{37}$. Na cześć Matki Bożej Loretańskiej powstawaly, i nadal powstaja, utwory poetyckie i pieśni. Nickiedy do znanych melodii pisano nowe słowa. Do dzisiaj w Sierpcu śpiewa się pieśn „Najwyższa Pani”, a w Krakowie "Gwiazdo śliczna, wspaniała, loretańska Maryjo". Popularna i we wszystkich prawie Loretach śpiewaną była pieśn "Zdrowaś, zdrowaś"38.

Pod koniec XVII w. dotarły do Polski pamiątkowe medale, wybite z polecenia papieża Innocentego XI z okazji zwycięstwa króla Jana III nad Turkami. Miały charakter pamiątkowy i ozdobny. Papież obdarowywał nimi królów, książęta i biskupów. Medale te były inspiracją do wykonania przez mennice polskie małych medalików loretańskich ze srebra, brązu lub cyny, przeznaczonych do noszenia na szyi. Przedstawiały najczęściej święty Domek w otoczeniu aniolów lub wizerunek loretański ${ }^{39}$.

W XVII w. rozpowszechniła się $w$ okolicy Ankony praktyka bicia $w$ dzwony podczas burzy celem wyjednania Bożego błogosławieństwa i milosierdzia. Z czasem pojawiły się małe dzwoneczki, które święcono w świętym Domku. Nazwano je loretańskimi. Zdobiono je postaciami aniolów lub świętego Domku. W XIX w. dzwoneczki loretańskie wykonywano na ziemiach polskich. Byly jeszcze popularne $w$ Polsce w I poł. $X X$ w. Używano je podczas burz i powodzi, a także w czasie odmawiania modlitw za konajacych. Dzwonki większych rozmiarów umieszczano w wieżyczkach obok kaplic i domków loretańskich oraz przy wejściach do klasztorów i kamiennic. Niekiedy można było spotkać dzwonki loretańskie umieszczone $w$ małych dzwonnicach lokowanych pośród uprawnych pól, jak to ma miejsce w Skomielnej Czarnej lub okolicach Stanisławowa ${ }^{40}$.

Niektóre sanktuaria loretańskie (Kraków - kapucyni, Stwołowicze, Praga, Sierpc) miały nadane papieskie odpusty, które można było uzyskać $w$ dowolnym dniu roku przez nawiedzenie domku czy kaplicy. W ośrodkach tych ustanowione byly pewne dni świąteczne, w których obchodzono pamiątkę erekcji Loretu. Dniem najbardziej uroczystym byl 10 grudzień, kiedy to wspominano dzień przeniesienia świętego Domku*1.

37 J. Marecki, Domek Matki Bo亡ej..., s. 60 (przypis .63).

38 L. Paprocki, dz. cyt., s. 3 nlb.; F. Janocha, Sierota i džronek loretański. Kraków 1896, s. 1-3; [A. Wojnar], dz. cyt., s. 94; A. Turowska, Jesteśmy w Loreto. W: U kresu. Kraków 1938, s. 93-94.

39 [E. Nowakowski], O cudownych obraznch..., s. 845; T. Rewoliński, Medale religijne. Kraków 1885 , s. 60 , tabl. 12; G. Santarelli, dz. cyt., s. 22; s. Librowski, Program prac nad medalami religijnymi. "Archiwa, Biblioteki i Muzea Kościelne". 2:1978, s. 67-68.

to J. Marecki, Domek Matki Bożej..., s. 61.

41 S. Barącz, dz. cyt., s. 121; [L. Doliński], dz. cyt., s. 32; [A. Wojnar], dz. cyt., s. 58. 
Praga pod Warszawą byla jedynym po Loreto miastem, które moglo poszczycić się herbem i pieczęcią z Matką Bożą Loretańską. Herb ten nadal miastu król Władyslaw IV w 1645 r., w czasie budowy Domku Loretańskiego na Pradze. Pieczęć praska przedstawia Matkę Bożą z Dzieciątkiem siedząca na świętym Domku podtrzymywanym przez aniolów ${ }^{42}$.

Loret praski i krakowski byly miejscami, w których spotykali się w latach niewoli polscy patrioci. Podobnie i pozostałe Lorety byly ośrodkami manifestacji polskości i dążeń narodowych Polaków w czasie zaborów. $W$ domku loretańskim w Krakowie, w dniu 24 marca 1794 r., przysięgał gen. Tadeusz Kościuszko i gen. J. Wodzicki walczyć w obronie Ojczyzny. Praski Loret był świadkiem walk stronników króla Augusta IIl i Leszczyńskiego podczas której miała się zapaść posadzka z moskiewskimi i saskimi żołnierzami. Podczas "rzezi Pragi"dokonanej 1794 r. przez wojsko gen. A. Suworowa część jej mieszkańców schroniła się do Loretu gdzie wszyscy zginęli. Ruiny klasztoru i wnętrze domku byly ulubionym miejscem spotkań warszawskiej młodzieży. $\mathrm{Z}$ praskiego Loretu pozostal sam domek otoczony szerokimi krużgankami. Przy świątyni tej w XIX w. erygowano parafię Matki Bożej Loretańskiej ${ }^{j 3}$.

W 1920 r. ks. Ignacy Klopotowski, proboszcz parafii loretańskiej w Warszawie, zalożyl zgromadzenie Sióstr Loretanek. Siostry te - zgodnie z wola założyciela - mialy prowadzić życie ciche i ukryte na wzór życia świętej Rodziny z Nazaretu i apostolować przez dzialalność pisarską, wydawnicza i charytatywna ${ }^{44}$.

W XVIII i XIX w. popularnym środkiem leczniczym byly ziólka i krople loretańskie, których używano podczas grypy i bólów żołądka. Można je bylo nabyć we wszystkich aptekach Krakowa. Wyrabiano je z ziół rosnacych w okolicy Loretu. Etykietki na butelkach przedstawiały łaskami słynąca figurę loretańską ${ }^{45}$.

Nowy etap kultu loretańskiego rozpoczął się w dniu 24 marca 1920 r., kiedy to papież Benedykt XV ogłosił Matkę Bożą Loretańską patronką lotników i wszystkich podróżujacych w powietrzu. W kilka lat później rozpoczẹto w Warszawie budowę kościoła p.w. Matki Bożej Loretańskiej w pobliżu lotniska na Okęciu, która ukończono w 1934 r. Obok wspomnianego kościola w ostatnich latach wzniesiono nowa światynie pod tym samym wezwaniem. Patronką polskich lotników, szybowników i wszystkich związanych z lotnictwem jest Czarna Pani z domku w Krakowie ${ }^{46}$.

Po drugiej wojnie światowej w granicach Polski znalazly się domki loretańskie iv Glogówku i Krzeszowie. Loret w Glogówku został wybudowany

\$2 J. Slowaczyński. Prnga. Paryż 1835, s. 8; S. Ulanecki, dz. cyt., s. 271; A. Dubowski, art. cyt., s. 198.

$\$ 3$ J. Marecki, Domek Matki Bożej..., s. 63-64.

\# Wsknzmin dla sióstr Loretanek. Warszawa 1981, s. 3-4. (Mps w Arch. Prow. Kr. OFM Cap.)

45 Reklamowalo je na terenie Galicji m.in. Czasopismo „Echo Krakowa” w latach 1880-1890.

16 [A. Wojnar], dz. cyt., s. 92. 
w 1634 r. przez rodzinę Oppersdorffów. Domek krzeszowski powstał w latach 1676-1678 a koszty budowy pokryl opat Bernard Rossa, który pielgrzymujac do Loreto uczynił ślub wzniesienia kościola ku czci Matki Bożej Loretańskiejłz.

Kult Matki Bożej czczonej $w$ loretańskich wizerunkach upadł na ziemiach polskich $w$ XIX w. Większość Loretów leżala na terenach zaboru rosyjskiego, gdzie kasaty carskie objely ponad polowę kościołów i kaplic loretańskich. Zaborcy kierowali się przede wszystkim chęcia latwego zdobycia bogactw, jakie w ich przeświadczeniu mialy być nagromadzone w tych sanktuariach. Dlatego niszczono i plądrowano wszystko, zrywano $\mathrm{z}$ obrazów i figur wota i kosztowności, a zdewastowane kościoly zamieniano na prawosławne cerkwie lub burzono. Zniszczono Lorety we Lwowie, Okielnikach, Olkuszu, Mińsku, Stwolowiczach i Telszach. Wcześniej, bo już w czasach Jana Kazimierza moskale zniszczyli kaplice loretańska $w$ Iwjach 48.

Do czasów obecnych zachowaly się jednak prawie wszystkie wizerunki loretańskie uważane przez wiernych za cudowne. Nadal odbieraja cześć i sa wyrazem kultu maryjnego charakterystycznego dla Polaków.

17 H. Dziurla, Krzeszóiv. Wroclaw 1974, s. 25-31, 70; J. Marecki, Wykaz ważniejszych ośrotkówo..., s. 1,3 .

t8 W.E. Radzikowski, Kraków Kraków [brw]], s. 46; [E. Nowakowski], dz. cyt., s. 228, 387, 449, 482, 635; W. [Gazda], art. cyt., s. 14 . 